\title{
FAKTOR-FAKTOR YANG MEMPENGARUHI PERMINTAAN TENAGA LISTRIK KONSUMEN INDUSTRI KECIL PT PERUSAHAAN LISTRIK NEGARA (PERSERO)
}

\author{
Aminuddin \\ Universitas Muslim Indonesia Fekon (UMI) Makassar \\ Amdis1960@yahoo.co.id
}

\begin{abstract}
This research is analysis of electricity demand, and focus for small industry sector in PT Perusahaan listrik Negara (Persero) or PT PLN (Persero). Dependent variable is demand electricity or $\mathrm{kWh}$ sales, and independent variable consist of install capacity, average tariff, and rate of capacity using percustomers. Step of research and process result based on SPSS calculation, and use cross section data on January 2010. Obtain result that install capacity has given positif impact, and average tariff and rate of capacity using percustomers has given negative impact. All of that independent variable has significant influence to electricity demand of small industry sector. PLN's management has to observe growth of explanatory variable to make policy for demand and supply equilibrium and toward customers satisfaction.
\end{abstract}

Key words : permintaan tenaga listrik, manajemen strategi, ekonomi mikro.

Perusahaan Listrik Negara (PLN) memiliki pelanggan yang dapat dibedakan kedalam berbagai kelompok, dalam studi ini difokuskan untuk kelompok konsumen industri kecil. Kelompok konsumen ini berjumlah sekitar 593 sambungan. Memahami struktur permintaan tenaga listrik konsumen industri kecil ini adalah sangat penting bagi pengambil keputusan agar dapat merumuskan kebijakan ketenagalistrikan konsumen ini dengan tepat, khususnya terhadap kebijakan pemerintah yang terkait dengan subsidi listrik yang disiapkan pemerintah dan sekaligus tarif yang akan diperlakukan PLN. Tanpa subsidi pemerintah, kelompok konsumen ini akan mengalami kendala yang cukup serius karena kemampuan daya beli yang sangat terbatas sehingga kemungkinan sulit untuk menjangkau atau menikmati aliran listrik. Disamping itu, PLN sulit melakukan investasi, bukan hanya karena daya beli konsumen yang relative rendah tetapi juga skala ekonomi dibeberapa kawasan masih relative kecil, sehingga kurang layak dari sisi keuangan perusahaan. Bagi perusahaan yang dikelola secara pure business, maka kondisi seperti ini sulit untuk dilaksanakan, namun karena campur tangan pemerintah melalui PLN, maka pelayanan kelistrikan konsumen industri kecil ini dapat direalisasikan, meskipun tidak layak atau merugikan PLN. 
Struktur permintaan tenaga listrik konsumen industri kecil antara lain dapat dikaji dengan menganalisis faktor atau variabel independen yang mempengaruhi konsumsi tenaga listrik konsumen industri kecil. Langkah yang perlu dilakukan dimulai dari mengidentifikasi faktor-faktor yang mempengaruhi permintaan tenaga listrik, selanjutnya mengukur besarnya pengaruh masing-masing faktor tersebut, kemudian menganalisis tingkat signifikansi pengaruhnya terhadap permintaan tenaga listrik konsumen industri kecil yang dalam hal ini sebagai variabel dependen. Tingkat signifikansi pengaruh variabel sangat penting peranannya, karena dapat menjadi acuan dalam kebijakan manajemen pada saat melakukan penentuan skala prioritas program kerja perusahaan.

Hal ini juga sangat bermanfaat dalam perumusan kebijakan manajemen bila perusahaan menghadapi keterbatasan pendanaan. Bila terdapat variabel yang kurang signifikan pengaruhnya terhadap permintaan tenaga listrik konsumen industri kecil akan memberikan informasi kepada manajemen bahwa perubahan yang terjadi terhadap variabel tersebut tidak akan berdampak serius terhadap perubahan permintaan tenaga listrik konsumen industri kecil. Manajemen tidak perlu menyiapkan sumberdaya atau pendanaan secara khusus terhadap program yang berkaitan dengan variabel yang tidak nyata pengaruhnya, bahkan tidak perlu secara berlebihan merespon jika terjadi perubahan variabel tersebut karena dampaknya tidak begitu nyata atau relative kecil pengaruhnya terhadap permintaan tenaga listrik konsumen industri kecil.

Jumlah konsumen industri kecil di berbagai wilayah yang dilayani oleh PLN pada tahun 2010 adalah 593 industri. Jumlah konsumen industri kecil yang dilayani oleh PLN terbanyak berada di Jawa Barat, menyusul Jawa Tengah, Jawa Timur dan DKI. Konsumen industri kecil di Pulau Jawa mencapai sekitar 351 sambungan atau sekitar 59\% dari jumlah konsumen ini. Sedangkan diluar Pulau Jawa jumlah konsumen industri kecil terbesar di Sumatera Utara 58 sambungann, Sulawesi Selatan-Barat-Tenggara 56 sambungan dan Sulawesi Utara-Tengah- Gorontalo 51 sambungan. Wilayah kerja PLN yang paling sedikit jumlah konsumen industri kecil, yaitu Lampung, Maluku, dan Papua masing-masing sebesar 1 sambungan. Konsumen industri kecil ini memiliki kapasitas arus listrik sekitar $450 \mathrm{VA}$ - $900 \mathrm{VA}$, sehingga penggunaan listriknya secara umum hanya untuk penerangan tempat usaha dan peralatan usaha elektronik yang sifatnya 
membutuhkan daya yang kecil karena pada kapasitas tersebut tidak cukup untuk peralatan-peralatan usaha yang berat.

Jumlah konsumen industri keseluruhan tahun 2009 tercatat 48 ribu sambungan sedangkan konsumen industri kecil mencapai 593 sambungan atau sekitar 1,2\% dari keseluruhan jumlah konsumen industri. Pemerintah memprioritaskan subsidi pada konsumen industri kecil ini, karena pada tingkat harga keekonomian secara umum sulit terjangkau oleh daya beli konsumen ini. Harga keekonomian tarif listrik maksudnya adalah tarif yang berlaku mencerminkan harga pokok penyediaan plus marjin tertentu. Hal ini semakin sulit dilakukan karena kondisi ekonomi akhir-akhir ini sangat memprihatinkan dan daya beli masyarakat menurun, banyak perusahaan melakukan pemutusan hubungan kerja, dan jumlah pengangguran meningkat. Semakin diperparah lagi sejak tahun 2004 pemerintah mengumumkan bahwa sampai tahun 2009 tidak akan ada kenaikan tarif dasar listrik, dengan alasan membantu meringankan beban masyarakat dan memberi peluang para pengusaha dan investor akan dapat segera berkembang usahanya dan menyerap tenaga kerja untuk memperkuat daya beli masyarakat.

Tahun 2010 jumlah konsumsi kWh konsumen industri kecil (tabel 1) diberbagai wilayah diproyeksikan akan meningkat karena tambahan kapasitas pembangkit baru dibeberapa lokasi mulai beroperasi sehingga daftar tunggu konsumen industri kecil secara bertahap dapat dilayani PLN, serta diharapkan akan ada program percepatan diversifikasi energi atau PPDE dengan kapasitas 10.000 MW akan segera beroperasi belum termasuk tambahan kapasitas pembangkit yang dikelola sektor swasta atau independent power purchasing (IPP) yang bermitra dengan PLN. Program PPDE merupakan terobosan dari kebijakan pemerintah untuk segera keluar dari krisis listrik yang dihadapi secara nasional. Pembangunan pembangkit tersebut menggunakan mesin pembangkit buatan China yang relative murah biaya investasinya dibanding merek lainnya. Jenis pembangkit tersebut adalah pembangkit listrik tenaga uap atau PLTU yang berbahan bakar batu bara kalori rendah dan banyak terdapat di Kalimantan dan Sumatera. Bila program PPDE terlaksana, maka supply tenaga listrik nasional dalam jangka menengah telah mampu memenuhi permintaan konsumen terutama industri kecil.

Daya terpasang sebagai salah satu variabel yang mempengaruhi permintaan listrik konsumen industri kecil, terbukti bahwa bertambahnya jumlah konsumen industri kecil 
diikuti juga oleh meningkatnya daya terpasang, kemudian secara konsisten diikuti oleh peningkatan konsumsi Kwh konsumen industri kecil.

Tabel 1

Daya Terpasang VA - Januari 2010

Kategori Industri Kecil

\begin{tabular}{|l|l|r|r|}
\hline No & \multicolumn{1}{|c|}{ UNIT } & \multicolumn{1}{|c|}{ VA } & Kontribusi(\%) \\
\hline 1 & Namgroe Aceh & 17.100 & 3.7 \\
2 & Sumatera Utara & 31.050 & 6.7 \\
3 & Sumatera Barat & 8.550 & 1.9 \\
4 & Riau & 0 & 0 \\
5 & Sumsel, Jambi,Bangkulu & 3.600 & 1.8 \\
6 & Bangka Belitung & 0 & 0 \\
7 & Lampung & 900 & 1.2 \\
8 & Kalimantan Timur & 3.150 & 0.7 \\
9 & Kalimantan Selatan dan Tenggara & 6.750 & 1.5 \\
10 & Kalimantan Timur & 3.600 & 0.8 \\
11 & Sulawesi Utara, Tengah, Gorontalo & 38.250 & 8.3 \\
12 & Sulawesi Tenggara, Barat, Tengah & 48.600 & 10.5 \\
13 & Maluku & 1.800 & 0.4 \\
14 & Papua & 900 & 0.2 \\
15 & NTB & 900 & 0.2 \\
16 & NTT & 3.150 & 0.7 \\
17 & Bali & 8.550 & 1.9 \\
18 & Jawa Timur & 35.550 & 7.7 \\
19 & Jawa Tengah & 91.800 & 19.9 \\
20 & Jawa Barat & 155.250 & 33.7 \\
21 & DKI & 1.800 & 0.4 \\
\hline & Total & $\mathbf{4 6 1 . 2 5 0}$ & $\mathbf{1 0 0} \%$ \\
\hline
\end{tabular}

Kontribusi daya terpasang konsumen industri kecil di Pulau Jawa mencapai sekitar 284 ribu VA atau sekitar 62\% dari besarnya daya terpasang konsumen ini, sementara jumlah konsumen industri kecil yang dilayani PLN terbanyak juga berada di Pulau Jawa yaitu 351 sambungan atau sekitar 59\% dari jumlah konsumen industri kecil. Sedangkan di luar Pulau Jawa kontribusi daya terpasang sekitar 177 ribu VA atau 38\% dari besarnya daya terpasang konsumen industri kecil, dimana kontribusi daya terpasang terbesar di Sulawesi Selatan-Barat-Tenggara 49 ribu VA, menyusul Sulawesi UtaraTengah-Gorontalo 38 ribu VA, dan Sumatera Utara 31 ribu VA, hal ini sejalan dengan jumlah konsumen industri kecil yang dilayani diluar Pulau Jawa terbesar juga ada di tiga wilayah tersebut yaitu Sumatera utara, Sulawesi Selatan-Barat-Tenggara dan Sulawesi Utara-Tengah- Gorontalo. Disini menunjukkan bahwa konsumsi kWh di Pulau Jawa lebih besar dibandingkan dengan diluar Pulau Jawa, sebagai akibat adanya peningkatan 
kesejahteraan masyarakat dan perkembangan teknologi, sehingga daya yang diperlukan juga semakin besar.

Dipulau Jawa pendapatan penjualan tenaga listrik mencapai Rp 11 milyar atau sekitar $131 \%$ dari keseluruhan pendapatan penjualan tenaga listrik konsumen industri kecil. Diluar Pulau Jawa pendapatan penjualan tenaga listrik terbesar dihasilkan dari Sumatera Utara Rp 49 milyar, Sulawesi Selatan-Barat-Tenggara Rp3,4 milyar dan Sulawesi Utara-Tengah-Gorontalo 3 milyar kWh. Sedangkan wilayah yang menghasilkan pendapatan penjualan listrik terendah dari Papua Rp 20 juta, Kalimantan Barat Rp 94 juta Maluku sebesar Rp 121 juta. Pendapatan penjualan tenaga listrik ini sejalan dengan besarnya kwh jual, yang berarti pendapatan penjualan tenaga listrik karena konsumsi Kwh konsumen industri kecil.

Pendapatan penjualan tenaga listrik tidak lepas dari struktur tarif listrik konsumen yang berlaku. Tarif yang berlaku saat ini dipertahankan sejak tahun 2004 sebagai komitmen pemerintah untuk membantu masyarakat yang kurang mampu. Sejak periode tersebut, tarif dasar listrik tetap terjaga meskipun beberapa kali usulan dari berbagai pihak untuk melakukan penyesuaian dengan alasan terlalu memberatkan anggaran pendapatan dan belanja negara atau APBN menanggung beban subsidi yang meningkat dari tahun ke tahun. Harga pokok penyediaan tenaga listrik jauh melebihi tarif rata-rata yang dibayar oleh konsumen.

Biaya bahan bakar yang dikeluarkan PLN mengalami kenaikan mengikuti tren harga bahan bakar internasional. Tahun 2004 harga bahan bakar minyak yang dibeli oleh PLN masih level yang sangat rendah sekitar Rp. 2.000 per liter dibanding harga bahan bakar saat ini telah mencapai sekitar Rp. 6.000 per liter. Dari segi biaya penyediaan listrik yang masih menggunakan bahan bakar minyak diperlukan volume sekitar 0,3 liter tiap Kwh produksi, sehingga biaya bahan bakar mencapai sekitar Rp. 2.000 per Kwh, sementara harga jual tahun 2009 rata- rata hanya pada kisaran Rp. 626 per Kwh. Berdasarkan laporan keuangan PLN jumlah subsidi yang ditanggung APBN berturutturut yaitu tahun $2006 \mathrm{Rp} 32$ triliun, tahun 2007 Rp 36 triliun, tahun 2008 Rp 78 triliun, tahun 2009 Rp 55 triliun, dan tahun 2010 dialokasikan Rp 62 triliun.

Tahun 2010 pemerintah telah merencanakan penerapan tarif baru atau penyesuaian TDL. Secara cash flow, kenaikan TDL tersebut tidak terlalu signifikan 
pengaruhnya terhadap kondisi keuangan PLN karena penyesuaian hanya mengurangi subsidi pemerintah yang selama ini diberikan ke PLN. Selama ini subsidi dicatat sebagai pendapatan usaha sebagaimana penjualan tenaga listrik, namun dengan penyesuaian TDL subsidi akan berkurang tetapi pendapatan penjualan tenaga listrik naik, namun secara total pendapatan usaha tidak mengalami peningkatan yang signifikan.

Kendala PLN yang paling utama saat ini adalah keterbatasan pendanaan untuk investasi, bahkan untuk kebutuhan operasi harus dipenuhi oleh subsidi pemerintah. Pemerintah, selama ini hanya menyediakan anggaran cukup buat biaya produksi, tidak ada untuk investasi. PLN berandil kurang maksimal dalam pemeliharaan dan perawatan pembangkit listrik, sehingga sejumlah pembangkit bekerja tidak maksimal. Itu terjadi karena pendanaan internal PLN lemah akibat rendahnya kebijakan tarif dasar listrik. Tarif dasar listrik diusulkan oleh PLN ke pemerintah melalui Dirjen Listrik dan Pengembangan Energi atau LPE, kemudian disetujui oleh Menteri Energi dan Sumber Daya Mineral atau ESDM, selanjutnya melalui persetujuan DPR, dan disahkan melalui Penetapan Presiden.

Tugas PLN selanjutnya, adalah mensosialisasikan ke konsumen dan menyiapkan langkah implementasinya agar tidak menimbulkan gejolak dalam masyarakat. Pengalaman pahit PLN pada saat kenaikan tarif listrik periode yang terakhir, mendapat protes diberbagai daerah dan berakhir dengan pembatalan penerapan tarif listrik yang baru. Setelah itu, pihak pengambil keputusan terutama Pemerintah dan DPR sangat hatihati dalam menyiapkan rancangan penyesuaian tarif dasar listrik karena alasan stabilitas dan resistensi masyarakat pada umumnya. Hal inilah yang menyebabkan jarak antara harga pokok penyediaan tenaga listrik sangat jauh dibanding tarif rata-rata yang dibayar oleh konsumen industri kecil sebagaimana dikemukakan pada tabel 2. 


\section{Tabel 2}

Tarif Rata-Rata Januari 2010

Kategori Industri Kecil

\begin{tabular}{|c|c|c|c|}
\hline No. & UNIT & Rp/kWh & $\%$ \\
\hline 1 & Nangroe Aceh Dar & 588 & $125 \%$ \\
\hline 2 & Sumatra Utara & 409 & $87 \%$ \\
\hline 3 & Sumatra Barat & 667 & $142 \%$ \\
\hline 4 & Riau & - & - \\
\hline 5 & Sumsel, Jambi, Benk & 683 & $145 \%$ \\
\hline 6 & Bangka Belitung & - & - \\
\hline 7 & Lampung & 527 & $112 \%$ \\
\hline 8 & Kalimantan Barat & 584 & $124 \%$ \\
\hline 9 & Kalimantan Sel \& Teng & 645 & $137 \%$ \\
\hline 10 & Kalimantan Timur & 586 & $125 \%$ \\
\hline 11 & Sulawesel utr, Teng, Gor & 575 & $122 \%$ \\
\hline 12 & Sulawesi Sel, Bar, Teng & 607 & $129 \%$ \\
\hline 13 & Maluku & 650 & $138 \%$ \\
\hline 14 & Papua & 5.028 & $1070 \%$ \\
\hline 15 & NTB & 487 & $104 \%$ \\
\hline 16 & NTT & 463 & $98 \%$ \\
\hline 17 & Bali & 494 & $105 \%$ \\
\hline 18 & Jawa Timur & 600 & $128 \%$ \\
\hline 19 & Jawa Tengah & 619 & $132 \%$ \\
\hline 20 & Jawa Barat & 544 & $116 \%$ \\
\hline 21 & DKI & 845 & $180 \%$ \\
\hline- & Total & 470 & $100 \%$ \\
\hline
\end{tabular}

Tarif dasar listrik mengalami kenaikan pada tahun 2003, kemudian setelah itu tidak lagi dilakukan penyesuaian sedangkan harga bahan bakar yang menjadi dominan dalam biaya pokok penyediaan tenaga listrik telah mengalami beberapa kali kenaikan. Saat ini pemerintah turut memikirkan hal ini dengan merumuskan sejumlah opsi kenaikan tarif dasar listrik atau TDL. Kenaikan TDL ini adalah kebijakan pahit yang harus diambil agar subsidi tidak bertambah dan kian membebani keuangan negara. Dalam beberapa opsi itu, rata-rata persentase kenaikan TDL untuk pelanggan listrik ditargetkan sekitar 12 persen yang disesuaikan dengan kemampuan bayar tiap golongan pelanggan.

Pemerintah telah membuat enam opsi kenaikan tarif dasar listrik, yang akan dibahas dan diputuskan bersama dengan DPR. Salah satunya, opsi TDL bagi golongan 900 volt ampere (VA) ke bawah tidak naik. Jadi, biaya untuk mengatasi kekurangan subsidi dipikul pelanggan lain. Opsi lain, TDL pelanggan 900 VA ke bawah naik, tetapi hanya 5 persen agar besaran kenaikan TDL untuk pelanggan lain tidak terlalu besar. Selain itu, ada opsi tarif listrik golongan pelanggan 6.600 VA ke atas tidak naik. Oleh karena, tarif keekonomian sudah diterapkan bagi pelanggan rumah tangga, bisnis, dan publik dengan daya 6.600 VA ke atas yang pemakaian listriknya melebihi 50 persen dari rata-rata konsumsi nasional. Alternatif lain, tarif keekonomian untuk kelompok 
pelanggan 6.600 VA ke atas yang pemakaian listriknya melebihi 30 persen rata-rata konsumsi nasional. Karena tarif rata-rata menjadi pemicu dalam pola penggunaan listrik konsumen, maka dalam analisis permintaan sektor ini mempertimbangkan tarif rata-rata per kWh yang dibayar oleh konsumen.

Dari latar belakang diatas maka tujuan dari penelitian ini adalah 1) mengetahui besarnya pengaruh variabel bebas daya terpasang konsumen industri kecil (KVIK) terhadap permintaan tenaga listrik konsumen industri kecil (KWIK), 2) memahami besarnya pengaruh perubahan variabel bebas tarif rata-rata konsumen industri kecil (TRIK) terhadap permintaan tenaga listrik konsumen industri kecil (KWIK), 3) mengetahui besarnya pengaruh perkembangan variabel bebas tingkat pemanfaatan kapasitas listrik konsumen industri kecil (TPIK) terhadap permintaan tenaga listrik konsumen industri kecil (KWIK) dan 4) memastikan variabel bebas yang paling signifikan pengaruhnya terhadap permintaan tenaga listrik konsumen industri kecil (KWIK).

\section{HIPOTESIS}

Adapun hipotesis pada penelitian ini adalah; (1) Daya terpasang volt ampere berpengaruh signifikan terhadap permintaan tenaga listrik konsumen industri kecil. (2) Tarif rata-rata perkwh yang dibayar oleh konsumen setiap bulan turut menentukan secara signifikan terhadap permintaan tenaga listrik konsumen industri kecil. (3) Tingkat pemanfaatan kapasitas arus listrik yang terpasang di tempat konsumen industri kecil, merupakan refleksi dari meningkatnya penggunaan peralatan elektronik yang turut mempengaruhi secara signifikan permintaan tenaga listrik konsumen industri kecil. (4) Daya terpasang dan tingkat pemanfaatan kapasitas arus listrik berpengaruh positif terhadap permintaan tenaga listrik konsumen industri kecil, sedangkan tarif rata-rata berpengaruh negatif terhadap permintaan tenaga listrik konsumen industri kecil.

\section{METODE}

Data yang dibutuhkan dalam penelitian ini terbagi menjadi dua yaitu data primer dan data sekunder. Data primer merupakan data yang diperoleh melalui wawancara dengan pihak terkait untuk memperoleh gambaran yang lebih konkrit terhadap obyek yang diamati. Data sekunder yang dibutuhkan merupakan data - data yang dikumpulkan 
baik dari internal perusahaan maupun dari eksternal. Data sekunder diperoleh dalam bentuk laporan periodik berupa laporan penjualan tenaga listrik, laporan keuangan, data kependudukan, dan lain-lain.

Populasi penelitian ini mencakup keseluruhan konsumen PLN dari industri kecil secara nasional. Sedangkan sampel yang dipilih adalah beberapa wilayah di Jawa-Bali dan diluar Jawa-Bali yang dianggap mewakili populasi. Konsumen industri kecil yang menggunakan daya listrik 450 VA sampai dengan 900VA. Dalam penelitian ini terdiri dari satu variabel terikat, yaitu permintaan tenaga listrik konsumen industri kecil (KWIK), dan beberapa variabel bebas, yaitu daya terpasang Volt ampere konsumen industri kecil (KVIK), tarif rata-rata konsumen industri kecil (TRIK), dan tingkat pemanfaatan kapasitas arus listrik konsumen industri kecil (TPIK). Lokasi dan waktu pengumpulan data dari penelitian ini, yaitu (a) lokasi penelitian di PT PLN (Persero) untuk memperoleh data konsumen industri kecil secara nasional, bulan Januari tahun 2010, (b) lokasi Biro Pusat Statistik atau BPS untuk memperoleh data kependudukan, pertumbuhan ekonomi tahun 1995 sampai dengan tahun 2009, (c) lokasi PLN Jawa Bali dan PLN luar Jawa Bali untuk memperoleh gambaran perilaku konsumen industri kecil.

Data sekunder yang dikumpulkan dari laporan penjualan tenaga listrik PLN, laporan keuangan PLN, data statistik PLN, dan Biro Pusat Statistik. Selanjutnya data tersebut ditabulasi sesuai dengan kepentingan penelitian. Hasil tabulasi diolah dengan menggunakan program SPSS versi 17.0. Teknis analisis dilakukan melalui beberapa tahap, yaitu diawali dengan inventarisasi variabel dan ketersediaan data, kemudian tahap selanjutnya memilih model analisis yang tepat untuk menggambarkan fenomena yang diamati. Teknik analisis ekonometrika digunakan untuk mengungkapkan hubungan antara variabel yang diteliti, baik secara teori ekonomi maupun berdasarkan kalkulasi perhitungan statistik. Model ekonometrika yang akan dipertimbangkan penggunaannya dalam analisis ini, terdiri dari model linear dan model non linear sebagai berikut :

Model linear :

$$
\mathrm{KWIK}=\mathrm{bo}+\mathrm{b} 1 \mathrm{KVIK}+\mathrm{b} 2 \mathrm{TRIK}+\mathrm{b} 3 \mathrm{TPIK}+\mathrm{U}
$$

Model Non linear :

$$
\text { Ln KWIK = bo + b1 ln KVIK + b2 Ln TRIK + b3 Ln TPIK + U }
$$

Dimana : 


$\begin{array}{lll}\text { Ln KWIK atau KWIK } & : & \text { Permintaan tenaga listrik konsumen industri kecil } \\ \text { Ln KVIK atau KVIK } & : & \text { Daya terpasang konsumen industri kecil } \\ \text { Ln TRIK atau TRIK } & : & \text { Tarif rata-rata konsumen industri kecil } \\ \text { Ln TPIK atau TPIK } & : & \text { Tingkat pemanfaatan arus listrik konsumen industri } \\ & & \text { kecil } \\ \text { b0 } & : & \text { Konstanta } \\ \text { b1,b2, dan b3 } & : & \text { Koefisien regresi variabel eksplantory } \\ \text { U } & : & \text { Error }\end{array}$

Pemeriksaan atau evaluasi ekonometrika yang dilakukan, meliputi uji hipotesis uji-F dan uji-t, koefisien determinasi $\left(\mathrm{R}^{2}\right)$, koefisien korelasi ( $\mathrm{r}$ ), standar error (Se), pemenuhan asumsi regresi linear klasik yaitu normalitas, multikolinearitas, heteroskedaktisitas, dan autokorelasi.

\section{PEMBAHASAN}

Penelitian dilakukan dengan menggunakan data cross section bulan Januari 2010 untuk menganalisis faktor-faktor yang mempengaruhi permintaan tenaga listrik konsumen industri kecil. Model analisis yang digunakan mengikuti distribusi datanya yaitu model non linear yang berbasis Ln dengan variabel terikat permintaan tenaga listrik konsumen industri kecil (Ln KWIK), dan variabel bebas terdiri dari daya terpasang volt ampere konsumen industri kecil (Ln KVIK), tarif rata-rata konsumen industri kecil (Ln TRIK), dan tingkat pemanfaatan kapasitas arus listrik konsumen industri kecil (Ln TPIK). Masing-masing variabel tersebut dikumpulkan datanya dalam bentuk tabulasi data. Selanjutnya, proses perhitungan dengan menggunakan program SPSS versi 17.0 dengan hasil sebagai berikut :

\section{Tabel 3}

Coefficients

\begin{tabular}{|c|c|c|c|c|c|}
\hline \multirow[b]{2}{*}{ Model } & \multicolumn{2}{|c|}{ Unstandardized Coefficients } & \multirow{2}{*}{$\frac{\text { Standardized Coefficients }}{\text { Beta }}$} & \multirow[b]{2}{*}{$\mathrm{t}$} & \multirow[b]{2}{*}{ Sig. } \\
\hline & $\mathrm{B}$ & Std. Error & & & \\
\hline 1 (Constant) & 24.604 & 6.952 & & 3.539 & .003 \\
\hline LnKVIK & .933 & .098 & .671 & 9.520 & .000 \\
\hline LNTRIK & -1.747 & .301 & -.405 & -5.808 & .000 \\
\hline LnTPIK & -2.177 & 1.016 & -.152 & -2.142 & .049 \\
\hline
\end{tabular}

a. Dependent Variable: LnKWIK 
Dari tabel tersebut diatas diperoleh persamaan regresi sebagai berikut :

\section{Ln KWIK = 24,604+ 0,933 Ln KVIK - 1,747 Ln TRIK - 2,1770 Ln TPIK}

Dari persamaan regresi tersebut dapat dijelaskan sebagai berikut; nilai konstanta (bo) sebesar 21,604 menunjukkan pengaruh faktor lainnya yang tidak diperhitungkan dalam penelitian ini. Koefisein regresi (b1) sebesar 0,933 menunjukkan besarnya pengaruh positif variabel daya terpasang terhadap permintaan kWh konsumen industri kecil. Setiap kenaikan daya terpasang akan menaikkan permintaan kWh konsumen industri kecil, demikian sebaliknya bila terjadi penurunan daya terpasang akan menyebabkan penurunan permintaan kWh konsumen industri kecil.

Koefisien regresi (b2) sebesar -1,747 menunjukkan besarnya pengaruh negatif variabel tarif rata-rata terhadap permintaan $\mathrm{kWh}$ konsumen industri kecil. Setiap kenaikan tarif akan menurunkan permintaan $\mathrm{kWh}$ konsumen industri kecil, demikian sebaliknya bila terjadi penurunan tarif akan mendorong peningkatan permintaan $\mathrm{kWh}$ konsumen industri kecil. Koefisien regresi (b3) sebesar -2,1770 menunjukkan besarnya pengaruh negatif variabel tingkat pemanfaatan kapasitas aliran listrik terhadap permintaan $\mathrm{kWh}$ konsumen industri kecil. Setiap penambahan tingkat pemanfaatan kapasitas akan menurunkan permintaan kWh konsumen industri kecil, demikian sebaliknya bila terjadi penurunan tingkat pemanfaatan kapasitas aliran listrik akan menyebabkan peningkatan permintaan $\mathrm{kWh}$ konsumen industri kecil.

\section{Uji Hipotesis}

\section{Uji-F}

Nilai F-hitung sebesar 77,879 dan sig 0,000 menunjukkan bahwa terdapat sekurangkurangnya satu variabel bebas berpengaruh signifikan terhadap permintaan tenaga listrik konsumen industri kecil.

\section{Tabel 4} ANOVA $^{b}$

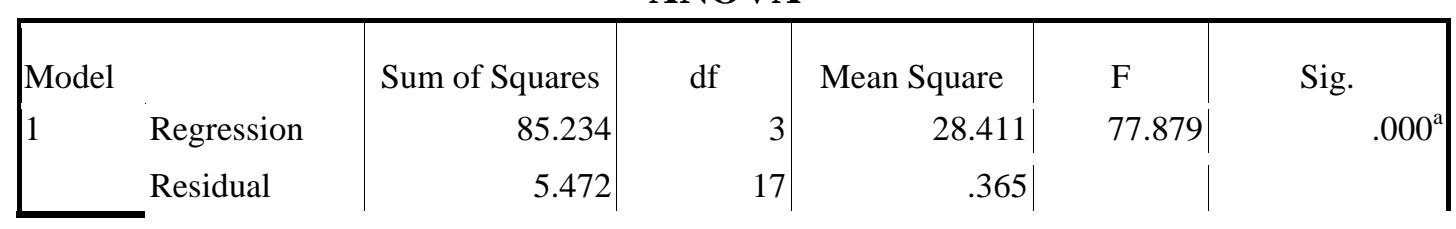




\begin{tabular}{|l|r|r|l|}
\hline Total & 90.707 & 20 & \\
\hline
\end{tabular}

a. Predictors: (Constant), LnTPIK, LnTRIK, LnKVIK

b. Dependent Variable : LnKWIK

\section{Uji-t}

Uji hipotesis ini digunakan untuk menguji secara individu dari koefisien regresi, dengan hasil sebagai berikut; variabel bebas daya volt ampere terpasang (KVIK) dengan nilai t-hitung 9,520 dan sig 0,000 menunjukkan bahwa variabel ini berpengaruh sangat signifikan terhadap permintaan tenaga listrik konsumen industri kecil. Variabel bebas tarif rata-rata konsumen industri kecil (TRIK) dengan nilai t-hitung sebesar 5,808 dan sig 0,000 menunjukkan bahwa variabel ini berpengaruh signifikan terhadap permintaan tenaga listrik konsumen industri kecil. Variabel bebas tingkat pemanfaatan kapasitas arus listrik (TPIK) dengan nilai t-hitung sebesar 2,142 dan sig 0,049 menunjukkan bahwa variabel ini berpengaruh signifikan terhadap permintaan tenaga listrik konsumen industri kecil .

\section{Koefisien determinasi $\left(\mathbf{R}^{2}\right)$}

Nilai $\mathrm{R}^{2}$ sebesar 0,940 menunjukkan bahwa model persamaan regresi yang digunakan dalam penelitian ini mampu menjelaskan fenomena yang diteliti sekitar 94\%, sedangkan sisanya sebesar $6 \%$ diterangkan oleh variabel lain yang tidak dimasukkan dalam model persamaan tersebut diatas.

\section{Tabel 5}

Model Summary

\begin{tabular}{|c|c|c|c|c|}
\hline & & & Adjusted R & \\
Model & $\mathrm{R}$ & R Square & $\begin{array}{c}\text { Std. Error of the } \\
\text { Estimate }\end{array}$ \\
\hline 1 & $.969^{\mathrm{a}}$ & .940 & .928 & .60400 \\
\hline
\end{tabular}

a. Predictors: (Constant), LnTPIK, LnTRIK,LnKVIK,

b. Dependent Variable: LnKWIK

\section{Koefisien korelasi (r)}

Hasil perhitungan SPSS diperoleh koefisien korelasi orde nol dan koefisien korelasi parsial atau orde pertama seperti pada tabel berikut ini :

\section{Tabel 6}




\section{Coefficients $^{\mathrm{a}}$}

\begin{tabular}{|c|c|c|c|c|c|c|c|c|c|c|c|c|}
\hline \multirow[b]{2}{*}{ Model } & \multicolumn{2}{|c|}{$\begin{array}{l}\text { Unstandard } \\
\text { ized } \\
\text { Coefficients }\end{array}$} & \multirow{2}{*}{$\begin{array}{c}\begin{array}{c}\text { Standar } \\
\text { dized } \\
\text { Coefficie } \\
\text { nts }\end{array} \\
\\
\\
\text { Beta }\end{array}$} & \multirow[b]{2}{*}{$\mathbf{t}$} & \multirow[b]{2}{*}{ Sig. } & \multicolumn{2}{|c|}{$\begin{array}{c}95.0 \% \\
\text { Confidence } \\
\text { Interval for } \\
\text { B }\end{array}$} & \multicolumn{3}{|c|}{ Correlations } & \multicolumn{2}{|c|}{$\begin{array}{l}\text { Collinearity } \\
\text { Statistics }\end{array}$} \\
\hline & B & $\begin{array}{l}\text { Std. } \\
\text { Error }\end{array}$ & & & & $\begin{array}{c}\text { Lowe } \\
\mathbf{r} \\
\text { Boun } \\
\mathbf{d}\end{array}$ & $\begin{array}{c}\text { Uppe } \\
\text { r } \\
\text { Boun } \\
\text { d }\end{array}$ & $\begin{array}{l}\text { Zero- } \\
\text { order }\end{array}$ & Partial & Part & $\begin{array}{c}\text { Toleranc } \\
\mathrm{e}\end{array}$ & VIF \\
\hline $\begin{array}{ll}1 & \text { (Const } \\
& \text { ant) }\end{array}$ & $\begin{array}{r}24.60 \\
4\end{array}$ & 6.952 & & 3.539 & .003 & 9.768 & $\begin{array}{r}39.42 \\
1\end{array}$ & & & & & \\
\hline $\begin{array}{l}\text { LnKVI } \\
\text { K }\end{array}$ & .933 & .098 & .671 & 9.520 & .000 & .724 & 1.142 & .865 & .926 & .604 & .810 & 1.234 \\
\hline $\begin{array}{l}\text { LnTRI } \\
\mathbf{K}\end{array}$ & 1.747 & .301 & -.405 & 5.808 & .000 & 2.388 & 1.106 & -.685 & -.832 & -.368 & .828 & 1.208 \\
\hline $\begin{array}{l}\text { LnTPI } \\
\mathrm{K}\end{array}$ & .2.177 & 1.016 & -.152 & 2.142 & .049 & 4.342 & -.011 & -.545 & -.484 & -.136 & .803 & 1.245 \\
\hline
\end{tabular}

a. Dependent Variable: LnKWIK

Dari koefisien korelasi orde nol dan koefisien korelasi orde pertama atau koefisien korelasi parsial menunjukkan bahwa variabel daya terpasang (KVIK) memiliki keterkaitan yang kuat dengan permintaan tenaga listrik konsumen industri kecil, dengan koefisien korelasi parsial sebesar 0,926. Variabel tarif rata-rata (TRIK) memiliki keterkaitan dengan permintaan tenaga listrik konsumen industri kecil dengan koefisien korelasi parsial sebesar 0,832 dan variabel tingkat pemanfaatan kapasitas aliran listrik (TPIK) memiliki keterkaitan dengan permintaan tenaga listrik konsumen industri kecil dengan koefisien korelasi parsial sebesar 0,484.

\section{Standar Error (Se)}

Dengan minimalnya standard error, maka koefisien yang didapat cenderung mendekati nilai sebenarnya. Ukuran minimal yang relatif, biasanya digunakan perbandingan besarnya parameter terhadap standard errornya. Bila rasio tersebut bernilai 2 atau lebih dapat dinyatakan bahwa nilai standard errornya relative kecil dibanding parameternya. Rasio ini menjadi acuan uji-t diatas. Hasil perhitungan Se melalui SPSS diperoleh, yaitu : (1) Variabel bebas daya terpasang (KVIK) dengan Se 0,098 dan nilai rasio parameter terhadap Se sebesar 9,5 atau sama dengan t-hit $(b j / \mathrm{Se}=0,933 / 0,098=9,5)$ 
menunjukkan bahwa Se variabel tersebut relatif kecil karena rasionya lebih besar dari (2) Variabel tarif rata-rata per $\mathrm{kWh}$ (TRIK) dengan Se 0,301 dengan rasio parameter terhadap Se sebesar 5,8 yang berarti standard errornya relative kecil karena rasionya lebih besar dari 2. (3) Variabel tingkat pemanfaatan kapasitas (TPIK) dengan Se 1,016 dan nilai rasio parameter terhadap Se sebesar 2,14 yang berarti standard errornya relative kecil karena rasionya lebih besar dari 2.

Variabel daya terpasang (KVIK) berpengaruh sangat signifikan terhadap permintaan tenaga listrik konsumen industri kecil dengan t-hitung 9,520 sig 0,000 dan koefisiein regresi 0,933. Koefisien regresi ini menunjukkan besarnya pengaruh positif variabel daya terpasang terhadap permintaan $\mathrm{kWh}$ konsumen industri kecil. Setiap kenaikan daya terpasang akan menambah permintaan kWh konsumen tersebut, demikian sebaliknya. Bila terjadi penurunan daya terpasang akan menyebabkan penurunan konsumsi kWh konsumen industri kecil. Dari segi ukuran keterkaitan antara variabel daya terpasang dengan permintaan tenaga listrik konsumen industri kecil sebagaimana koefisien korelasi parsial mencapai 0,926 lebih kuat keterkaitannya dibanding variabel bebas lainnya. Bila PLN terus melayani permohonan penyambungan baru dan tambah daya, tanpa penambahan kapasitas pembangkitan, maka akan menyebabkan excess demand, terjadi penurunan beban, mengganggu peralatan elektronik konsumen karena tegangan tidak stabil, dan frekuensi pemadaman meningkat. Pemadaman tersebut dapat terjadi karena pemadaman terencana maupun karena gangguan sistem penyaluran. Penambahan daya konsumen sangat sensitif terhadap permintaan tenaga listrik konsumen industri kecil, sehingga perlu dikendalikan keseimbangannya dengan kapasitas supply. Namun, tidak mengabaikan bila terjadi waiting list yang berlarut karena dapat memicu ketidak puasan konsumen akan pelayanan PLN. Disinilah pilihan manajemen antara memenuhi atau menangguhkan pelayanan penyambungan baru dan tambah daya yang diminta oleh konsumen.

Keterkaitan antara variabel tarif rata-rata (TRIK) dengan permintaan tenaga listrik konsumen industri kecil menunjukkan tingkat keterkaitan yang kuat sebagaimana koefisien korelasi parsial mencapai 0,832. Variabel tarif rata-rata (TRIK) pengaruhnya signifikan terhadap permintaan $\mathrm{kWh}$ dengan t-hitung 5,808 sig 0,000 dan koefisien regresi -1,747. Koefisien regresi tersebut menunjukkan besarnya pengaruh negatif 
variabel tarif rata-rata terhadap permintaan $\mathrm{kWh}$ konsumen industri kecil. Setiap kenaikan tarif akan menurunkan permintaan tenaga listrik konsumen tersebut, demikian sebaliknya bila terjadi penurunan tarif akan mendorong peningkatan konsumsi $\mathrm{kWh}$ konsumen industri kecil. Dalam kondisi keterbatasan kapasitas pembangkitan, penurunan permintaan konsumen akan mengurangi subsidi pemerintah, karena tarif tersebut jauh lebih rendah dari biaya pokok penyediaan yang dikeluarkan PLN.

Kendala yang dihadapi dalam penyesuaian tarif dasar listrik adalah resistensi dari berbagai pihak dengan berbagai alasan terutama karena daya beli masyarakat yang relatif memprihatinkan, perlu dukungan terhadap dunia usaha, perlu pengembangan industri, dan masih tersedia banyak alternative untuk memproduksi listrik dengan biaya murah. Namun, saat ini pemerintah sedang merumuskan untuk melakukan penyesuaian tarif dasar listrik tersebut, dimana menurut perhitungan tingkat pendapatan yang dibutuhkan PLN sekitar Rp 155,90 triliun, sementara pendapatan penjualan tenaga listrik sebesar Rp 95,8 triliun sehingga kebutuhan subsidi listrik tahun 2010 Rp 60 triliun. Akan tetapi, alokasi subsidi oleh pemerintah dalam APBN Perubahan 2010 hanya sebesar Rp 55,15 triliun, masih kurang Rp 4,85 triliun. Kekurangan dana ini ditutup pelanggan mampu lewat kenaikan TDL rata-rata 12 persen.

Keterkaitan antara variabel tingkat pemanfaatan kapasitas (TPIK) dengan permintaan tenaga listrik konsumen industri kecil menunjukkan tingkat keterkaitan yang substansial sebagaimana koefisien korelasi parsial mencapai 0,484. Tingkat keterkaitan variabel ini terhadap permintaan $\mathrm{kWh}$, ternyata relative kecil dibanding variabel daya terpasang dan variabel tarif rata-rata konsumen industri kecil. Variabel tingkat pemanfaatan kapasitas (TPIK) pengaruhnya signifikan terhadap permintaan $\mathrm{kWh}$ dengan t-hitung 2,142 sig 0,049 dan koefisien regresi sebesar -2,177, hal ini menunjukkan besarnya pengaruh negatif variabel tingkat pemanfaatan kapasitas aliran listrik terhadap permintaan kWh konsumen industri kecil.

Setiap penambahan tingkat pemanfaatan kapasitas aliran listrik akan menurunkan permintaan konsumen tersebut, demikian sebaliknya bila terjadi penurunan tingkat pemanfaatan kapasitas aliran listrik akan menyebabkan peningkatan konsumsi kWh konsumen industri kecil. Tingkat pemanfaatan kapasitas merepleksikan perkembangan teknologi atau alat elektronik yang digunakan konsumen industri kecil. Juga 
merefleksikan peningkatan kinerja industri yang mendorong menggunakan kapasitas yang lebih besar dan akhirnya mengkonsumsi listrik lebih tinggi. Penambahan pemanfaatan kapasitas meningkat bila tiap konsumen proporsi penggunaan kapasitasnya meningkat. Namun bila konsumen industri kecil bertindak arif dalam pemakaian peralatan elektronik dengan mengikuti anjuran pemerintah untuk melakukan penghematan dalam pemakaian listrik, maka peningkatan konsumsi energi listrik konsumen industri kecil yang disertai kehati-hatian dalam pemakaian listrik agar biaya yang dikeluarkan untuk membayar tagihan PLN tidak meningkat, maka hal ini tidak akan merubah tingkat pemanfaatan kapasitas arus listrik.

\section{KESIMPULAN DAN SARAN}

\section{Kesimpulan}

Adapun kesimpulan dalam penelitian menunjukkan bahwa variabel daya terpasang (KVIK) berpengaruh positif terhadap permintaan tenaga listrik konsumen industri kecil, yang berarti bahwa tiap pertambahan variabel ini akan menyebabkan pertambahan permintaan kWh konsumen industri kecil. Demikian sebaliknya bila terjadi penurunan variabel bebas tersebut. Variabel tarif rata-rata (TRIK) dan tingkat pemanfaatan kapasitas arus listrik (TPIK) berpengaruh negatif terhadap permintaan tenaga listrik konsumen industri kecil, yang berarti bahwa tiap pertambahan variabel ini akan menyebabkan penurunan permintaan $\mathrm{kWh}$ konsumen industri kecil. Demikian sebaliknya bila terjadi penurunan variabel bebas tersebut. Variabel daya terpasang paling signifikan pengaruhnya terhadap permintaan tenaga listrik konsumen industri kecil, menyusul variabel tarif rata-rata dan variabel tingkat pemanfaatan kapasitas. Tingkat signifikansi uji-t masing-masing variabel tersebut, yaitu (a) daya terpasang : t-hitung 9,520 dan sig 0,000, (b) tarif rata-rata: t-hitung 5,808 dan sig 0,000, (c) tingkat pemanfaatan kapasitas ; t-hitung 2,142 dan sig 0,049.

\section{Saran}

Beberapa hal yang bisa disarankan dalam menyiapkan kebijakan sebagaimana tertuang dalam perencanaan korporat, hendaknya memperhatikan secara prioritas terhadap perkembangan daya terpasang konsumen industri kecil. Mengingat penambahan 
daya terpasang sangat sensitif terhadap permintaan tenaga listrik konsumen industri kecil sehingga seyogyanya pelayanan tambah daya dan penyambungan baru disesuaikan dengan ketersediaan kapasitas pembangkit dan sistem penyaluran PLN sehingga tidak pernah didengar lagi adanya pemadaman bergilir akibat pemakaian listrik yang melampaui kapasitas maksimum supply PLN atau banyaknya peralatan elektronik konsumen yang rusak dampak dari kualitas listrik yang disalurkan kekonsumen kurang memuaskan. Untuk itu pengendalian terhadap pelayanan tambah daya dan penyambungan baru perlu ditingkatkan oleh PLN dengan menerapkan kebijakan dan peraturan kelistrikan tentang tambah daya dan penyambungan baru secara tegas untuk menghadapi tekanan dari berbagai pihak.

Kebijakan tarif sebagai salah satu faktor yang sangat sensitive terhadap resistensi oleh masyarakat pada umumnya. Meskipun variabel ini berpengaruh signifikan terhadap permintaan $\mathrm{kWh}$, namun hendaknya mengkaji secara komprehensif sebelum mengambil kebijaksanaan terhadap penyesuaian tarif dasar listrik tersebut. Berkaitan dengan hal tersebut Pemerintah dan DPR telah memberikan solusi pada esensi pokoknya yaitu melakukan penyesuaian tarif dasar listrik secara bijak, sehingga tidak hanya menyediakan pemberian subsidi. Disarankan dalam penyesuaian tarif dasar listrik dapat dilakukan secara bertahap dan perlu sosialisasi yang intensif untuk meyakinkan masyarakat khususnya konsumen industri kecil agar tidak terjadi resistensi.

Adanya penyesuaian tarif dasar listrik yang sedang dirumuskan oleh pemerintah, disarankan nantinya PLN dapat memperbaiki kinerja pendanaan internal PLN, sehingga mampu memaksimalkan pemeliharaan dan perawatan pembangkit listrik. Perkembangan teknologi dan peningkatan kinerja industri merepleksikan variabel bebas tingkat pemanfaatan kapasitas ternyata berpengaruh terhadap permintaan $\mathrm{kWh}$ konsumen industri kecil. Disarankan agar PLN mengupayakan penyediaan sistem supply secara berimbang mengikuti pertumbuhan variabel ini, disamping tetap memprioritaskan untuk mempertahankan pada kualitas atau tegangan tertentu agar aliran listrik yang dinikmati konsumen industri kecil memenuhi standar mutu layanan yang memadai. Sedangkan bagi Pemerintah disarankan untuk mampu memberikan perangkat kerja kepada PLN sebagai pelaksana jasa kelistrikan, sehingga subsidi yang diberikan ke PLN dari APBN, tidak 
hanya mempertimbangkan biaya produksi tapi juga memperhitungkan kebutuhan pendanaan investasi PLN

\section{DAFTAR RUJUKAN}

Agunan P. Samosir. 2004. Implikasi dari UU No. 20 Tahun 2002 Tentang Ketenagalistrikan Terhadap Kebijakan Subsidi Listrik Kedepan. Bunga Rampai Hasil Penelitian 2004. Jakarta. Vol. 12, No. 11, p. 77-93

Agus Sugiyono. 2000. "Indikator Pembangunan Tenaga Listrik yang Berkelanjutan (Sustainable Electricity Development Indicator)". Jurnal Energy Resources Development Technology, Badan Pengkajian dan Pengembangan Teknologi (BPPT), Jakarta, Indonesia. Vol. 23, No. 2, p. 637-648

Anay Vete. 2005. "Price Elasticity of Electricity : The Case of Urban Maharashtra. Tariff Reform in India". Journal of Econpapers - Swedish Business Scchool at Orebro University. Vol. L94, No. 32, p. 1-25 
Cades. 1999. "Hasil Studi Perencanaan Energy Nasional Jangka Panjang "CADES" (Comprehensive Assessment of Different Energy Sources for Electricity Generation In Indonesia)". Jurnal Energy Resource Development Technology, Badan Pengkajian dan Pengembangan Teknologi (BPPT), Jakarta, Indonesia. Vol. 2, No. 1, p. 11-17

Chairul Hudaya. 2008. "Pembangkit Listrik Tenaga Nuklir (PLTN) Sebagai Solusi Alternatif Kekurangan Listrik Nasional". Jurnal Tenologi Nuklir - Nuclear ffor Peace Purpose, Domar Gujarati dan Sumarno Zain.1978. Ekonometrika dasar. Penerbit Erlangga Jakarta.

Edwin Mansfield. 1997. Applied Microeconomics. W.W. Norton \& Company. New York.

Eugene F. Brigham and Michael C. Ehrhardt. 2002. Financial Management. South Western- Thomson learning. London

Evan J. Douglas.1995. Managerial Economics - Analysis and Strategy. Simon \& Schuster.Singapore.

Jeffrey M. Perloff. 2001. Microeconomics. Addison Wasley. New York.

Prathama Rahardja dan Mandala Manurung. 2006. Teori Ekonomi Mikro - Suatu Pengantar. LPFE - UI. Jakarta.

Sri Mulyono. 2006. Statistika - Untuk Ekonomi dan Bisnis. LPFE - UI Jakarta

Anay Vete. 2005. Price Elasticity of Electricity: The Case of Urban Maharashtra. Tariff Reform in India.

Muhammad Nasir and Ankasha Arif. 2008. Residential Demand for Electricity in Pakistan. Pakistan Institute of Development Economics (PIDE). Islamabad Pakistan

Peter C. Reiss and Mathew Q. White. 2001. Household Electricity Demand. Stanford University. Standford

Shu Fan and Rob J Hyndman. 2008. The Price Elasticity of Electricity Demand in South Australia and Victoria. Monash University. Australia.

Agunan P. Samosir.2004. Implikasi dari UU No. 20 Tahun 2002 Tentang Ketenagalistrikan Tehdap Kebijakan Subsidi Listrik Kedepan. Bunga Rampai Hasil Penelitian 2004. Jakarta.

Agus Sugi. 2000. Indikator Pembangunan Tenaga Listrik yang Berkelanjutan (Sustainable Electricity Development Indicator). Badan Pengkajian dan Pengembangan Teknologi (BPPT). Jakarta.

Chairul Hudaya. 2008. Pembangkit Listrik Tenaga Nuklir (PLTN) Sebagai Solusi Alternatif Kekurangan Listrik Nasional. Jakarta.

Nuryanti. 2007. Karakteristik Konsumsi Energi pada Sector Rumah Tangga di Indonesia. Jakarta.

Muhammad Nasir and Ankasha Arif. 2008. Residential Demand for Electricity in Pakistan. Journal of Pakistan Institute of Development Economics (PIDE) and also 
publicized Econpapers, Swedish Business School at Orebro University. Vol. 47, No. 4, p. 457- 467

Nuryanti. 2007. "Karakteristik Konsumsi Energi pada Sector Rumah Tangga di Indonesia". Jurnal Sekolah Tinggi Teknologi Nuklir - Batan, yang juga dipresentasikan pada seminar Nasional III SDM Teknologi Nuklir, Jakarta. Edisi 2010-09-10, p. 171-182

Peter C. Reiss and Mathew Q. White. 2001. "Household Electricity Demand. Stanford University. Standford”. Journal of Report Nepal - All-2001-12-2. Edisi 2010, p. $1-26$

PT PLN. 2010. Ikhtisar Penjualan Tenaga Listrik - PT PLN (Persero) Tahun 1995 2009. Jakarta. 